\title{
SERPINA7 wt Allele
}

National Cancer Institute

\section{Source}

National Cancer Institute. SERPINA7 wt Allele. NCI Thesaurus. Code C106004.

Human SERPINA7 wild-type allele is located in the vicinity of Xq22.2 and is approximately $6 \mathrm{~kb}$ in length. This allele, which encodes thyroxine-binding globulin protein, is involved in thyroid hormone transport. Mutation of the gene is associated with thyroxine-binding globulin deficiency. 